\title{
EFFICIENCY ENHANCEMENT OF SILAGE MAKING FROM FISH WASTES
}

\author{
Said Elshahat Abdallah ${ }^{1}$, Wael Mohamed Elmessery ${ }^{2}$, \\ Magda Mohamed Abdelrahman ${ }^{3}$ and Ahmed Ali Abdelglil ${ }^{4}$
}

\section{ABSTRACT}

The present study was to investigate the suitability of using fish wastes as raw material for silage making. To describe some of the major engineering and physical aspects of ensiling process, the following factors were considered as follows: four different mixing ratios of fish waste with rice bran, 1.5:1, 2.34:1,3.35:1 and 4:1; three different formic acid additions 2, 3 and 4\%; four diverse pressing pressure 7.85, 12.75, 17.65 and 22.56kPa; two unlike packaging color white and black and three dissimilar ranges of temperature $25-35,35-45$ and $45-55^{\circ} \mathrm{C}$ during harvesting time. The experimental results showed that the best mixing ratio of fish waste with rice bran was 3.35:1 which gives moisture content of $62.3 \% \mathrm{wb}$. The shortest ensiling period of 25 days was achieved at pressing pressure of $22.56 \mathrm{kPa}$, formic acid adding of $4 \%$ and black coverage color. However, the ensiling period tremendously decreased under controlled surrounding temperature at a range of $45-$ $55^{\circ} \mathrm{C}$ at the $9^{\text {th }}$ day; the $\mathrm{pH}$ of silage material was 3.25, total volatile fatty acid was of $1.95 \mathrm{~g} / \mathrm{kg}$ dry matter, Lactic acid bacteria was $6.2 \mathrm{~g} / \mathrm{kg}$ dry matter, crude protein was of $36.12 \%$, maximum temperature observed at the end of fermentation period at the $6^{\text {th }}$ day was of $36.1^{\circ} \mathrm{C}$, minimum temperature was at the $9^{\text {th }}$ day was of $23.4^{\circ} \mathrm{C}$ at $9^{\text {th }}$ day (harvesting day), the intensity of illumination value was of $44.5,47.3,53.3$ and 58.3 lumen $/ \mathrm{m}^{2}$ at material thickness of $4 \mathrm{~cm}$ at fermentation time of $3^{\text {rd }}, 6^{\text {th }}, 9^{\text {th }}$ and $12^{\text {th }}$ day respectively.

Keywords: fish silage, silage techniques, fish silage making, aquaculture, fish wastes

\footnotetext{
${ }^{1}$ Professor of Agricultural Process Engineering, Department of Agricultural Engineering, Faculty of Agriculture, Kafrelsheikh University, Egypt

${ }^{2}$ Associate Professor of Agricultural Process Engineering, Department of Agricultural Engineering, Faculty of Agriculture, Kafrelsheikh University, Egypt

3 Researcher Head, Agricultural Engineering Research Institute, Dokki, Giza, Egypt

4M.Sc. Student, Department of Agricultural Engineering, Faculty of Agriculture,

Kafrelsheikh University, Egypt
} 


\section{INTRODUCTION}

I

n Egypt the demand for animal protein is expected to increase progressively with each increase in human population. Fisheries sector plays a major role in alleviating protein deficiency and malnutrition, generating employment and foreign exchange earnings in Egypt. Besides, utilization of least-cost fishery wastes into powder by drying as (Abdallah et al., 2017). Making silage from fish can minimize feed cost and thus reduce cost of aquaculture production. Egypt produces from natural resources 335613 ton/year and from fish farmers 1370660 ton/year with a total production of 1706273 ton/year and total fish waste of 230346 ton/year (MALR, 2016). There are some potential for gaining more value from fish wastes. Fish are rich in valuable minerals, enzymes, pigments and flavors that are required by many industries including food, agriculture, aquaculture and pharmaceuticals (Archer et al., 2001). Good silage has a range of Lactic Acid Bacteria of (3.03 - 13.6g/kg dry matter) and Total Volatile Fatty Acid from 1.22 to $3.54 \mathrm{~g} / \mathrm{kg}$ dry matter (Gaafar, 2001 and Hossain, 2014). Fish waste represents half of the raw material volume of the processing industry and is a source of low-cost nutrients (Oetterer, 2002). The $\mathrm{pH}$ should be of 4 or lower to prevent bacterial spoilage. Therefore, the silage production tanks are acid resistant (Rose $\boldsymbol{e t}$ al., 2003). Silage technology is recognized as being the most useful one for solving wastes problem in fish industry. This procedure is safe, cost effective and eco-friendly too (Hanafy and Ibrahim, 2004). Rice bran contains 18 to $22 \%$ lipid. The carbohydrate and ash of rice bran varied from 25.9- $47.1 \%$ and $7.7-11.1 \%$ respectively (Cicero and Derosa, 2005). The use of fish silage in fish feeding has been widely studied. Due to the similarity of this protein source with the raw material and low cost, especially when compared to fish meal, silage has a high potential use in aquaculture (Goddard and Perret, 2005 and Arruda et al., 2007). Silage can be defined as livestock feed that has been preserved through acidification. The acidic environment required for proper ensiling to take place results via fermentation in the absence of $\mathrm{O}_{2}$ (Hancock and Collins, 2006). Ensilage processes are examples of without inoculation, SolidState Fermentation refers to the cultivation of microorganisms on moist solid supports (Chen, 2009). They prepared silage from viscera of 
different fish. Silage which made from herring offal contained 13.5\% crude protein, $8.7 \%$ lipid, $75.4 \%$ moisture and $2.6 \%$ ash. Silage that made from white fish offal contained $15.0 \%$ crude protein, $0.5 \%$ lipid, $78.9 \%$ moisture and 4.2\% ash (Abowei and Tawari, 2011). These fish wastes are an important source of proteins and lipids and therefore special efforts are being made to recover these valuable substances (AMedrzyck and Wandzei, 2013). A fish generally contains $45 \%$ flesh, $24-27 \%$ head, $12 \%$ skeleton, $3 \%$ skin, $4 \%$ cut off and $12 \%$ viscera including egg, milk and liver of its total body weight (DOF, 2013). Some scientist accepted the $\mathrm{pH}$ level $(3.9-4.2)$. The demand for fish increased with increasing human populations. However, it has been estimated that for each ton of fish eaten, an equal volume of fish material were discarded either as waste or as a low value by product, it contain high amount of protein, lipid and mineral (Karim et al., 2015).

The main aim of the current study is to reduce the period of silage harvesting and find unconventional and alternative rations with producing silage from wastes of agricultural and fish production. The specific objectives are drawn as follows:

1. Experimenting four different mixed ratios (1.5: 1$),(2.34: 1)$, (3.35: 1$)$ and (4: 1$)$ fish waste: rice bran, to determine the best mixed ratio for making silage.

2. Studying the effect of three different additions of formic acid (2, 3 and $4 \%$ ) on the fermentation time.

3. Investigating four different pressing pressures $(7.85,12.75,17.65$ and $22.56 \mathrm{kPa}$ ) on the fermentation time.

4. Studying the effect of two covering colors (white and black) on the fermentation time.

5. Investigating the effect of three different ranges of temperature 25 $-35,35-45$ and $45-55^{\circ} \mathrm{C}$ on the fermentation time.

\section{MATERIALS AND METHODS}

The present work was carried out at the laboratory of Rice Mechanization Center at Meet Eldeebah, Qellin district, Kafr Elsheikh Governorate with co-operation of Sakha Animal Production Research Station and Aquaculture Research Station during the period from February to December 2016. 


\section{Materials}

Fish wastes were obtained from Elshakhloubah market, located in Sedi Salem, Kafr Elsheikh governorate, Egypt. They were grinded using mincing machine of $5 \mathrm{~mm}$.

Rice bran of variety Sakha 178 was used, in picture bulk solids materials, with a bulk density of $0.29 \mathrm{~g} / \mathrm{cm}^{3}$, Crude Protein $12-15 \%$, crude fat $15-$ $22 \%$, crude fiber $7-11 \%$, crude ash $6.6-9.9 \%$, carbohydrate $34-52 \%$ ( El Kholy et al., 2009 ).

\section{Experimental Procedures and Measuring Instruments}

\section{Experimental Treatments}

Fish waste silage making experiments were conducted as follows:

First Experimental run: In this experimental run, it was studied of four different mixing ratios 1.5: 1, 2.34: 1, 3. 35: 1 and 4: 1, fish waste: rice bran. The mixing ratio 3.35: 1 , fish waste: rice bran was selected because it gives moisture content of $62.3 \% \mathrm{wb}$ and this percentage was recommended with it to make silage and appropriate for microorganisms environment according to previous studies as recommended by MAFR, 2006.

Second Experimental Run: According to the results obtained by the first experimental run, the optimum mixing ratios 3.35: 1, fish waste: rice bran was achieved. Three factors were studied in this experiment : the effect of three different formic acid additions of 2,3 and $4 \%$ and investigate four different pressing pressures of $7.85,12.75,17.65$ and $22.56 \mathrm{kPa}$ by manual pressure piston device with a measurement scale of $50 \mathrm{~kg}_{\mathrm{f}}$ to exclude the air occulted in the porous space of the material under study until maturity and the effect of two packaging material colors ( white and black ) on silage harvesting time .

Pressing Unit was consisted of compression unit and the manually pressure piston device were locally fabricated to measure silage pressure (Pascal). It was manufactured from iron sheets (3mm in thickness). Compression box has dimension of 15, 10 and $10 \mathrm{~cm}$ of length, width and height respectively. It was provided with a movable tray to take experimental treatment after compression and it has an iron cover with thickness of $5 \mathrm{~mm}$ to resist the load of compression and uniformly transfer this load to the material under compression. 
Packaging Process consists of two packing bags, inner plastic bag (transparent) and outer one (black or white) and outer packing of plastic bags (black or white) from polyethylene. Seventy two of identical plastic bags (polyethylene) were divided into two haves as: the first half is black and the second half is white above small cylindered plastic bags (double plastic bags). The black plastic bags pigments by dioxins material to give it the black color and containing its material, the properties of white plastic are made from polyethylene. The full capacity of each experimental treatment is about $400 \mathrm{~g}$., each experimental treatment is pressed by manual pressure piston device with a measurement scale of $50 \mathrm{~kg}_{\mathrm{f}}$ to exclude the air occulted in the porous spaces of the material under study until maturity from the bags and ensiled until maturity. It was used formic acid $85 \%$ in the experimental work. For measuring the change in bulk temperature of fish silage through fermentation period, thermocouples were put at the center of each sample and a sealing material was used to completely close the sample to assure full sealing of each sample. Figure 1 presents a schematic diagram for a sample of the used experimental treatment and distribution of the thermocouples inside each sample.

Third Experimental Run: In this experimental trial, temperature was considered as an important factor because it kills unwanted microorganisms. Temperature incubator was modified to manage different ranges of temperature as follows: $25-35,35-45$ and $45-55^{\circ} \mathrm{C}$ and this experimental run is consisting of incubator and control unit.

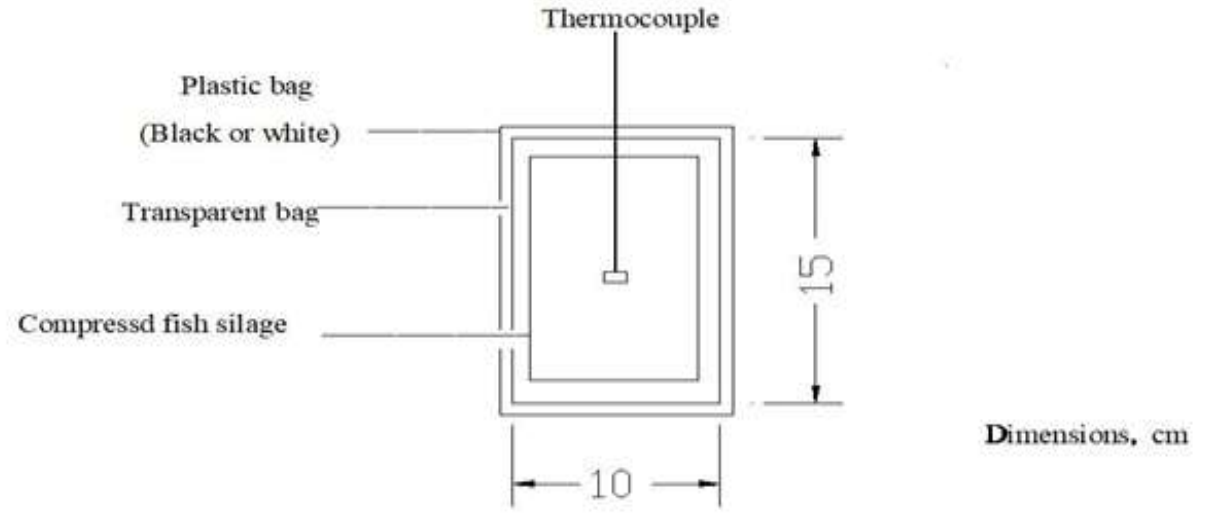

Figure 1. Position of thermocouples inside the plastic bags used for silage making experiments 


\section{Incubator}

Three incubation units of wood (15 mm in thickness) with thermal conductivity (heat flux) $0.17 \mathrm{~W} / \mathrm{m} .{ }^{\circ} \mathrm{C}$, dimensions of $60 \mathrm{~cm}$ length, $40 \mathrm{~cm}$ width and $20 \mathrm{~cm}$ height were installed for this experiment. Each incubator box has a door with a dimension of $60 \times 40 \mathrm{~cm}$. Each incubator was covered externally by thermal wood film, containing internally an electrical lamp (heating source) of 100 Watt as a heater. Each incubator contains nine experimental treatments of silage mixture (silage bag) and two thermocouples, the first one located at the inside of silage bag to measure the temperature of the silage directly and the second one located inside the incubator to measure the surrounding temperature of silage samples.

\section{PIN CONNECTIONS}

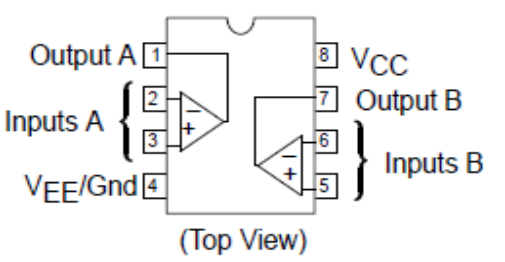

Figure 2. Connection diagram of the operational amplifiers LM358

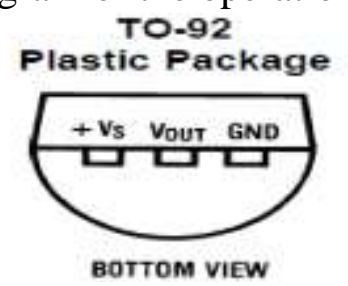

Figure 3. Connection diagram of temperatures sensor of LM35

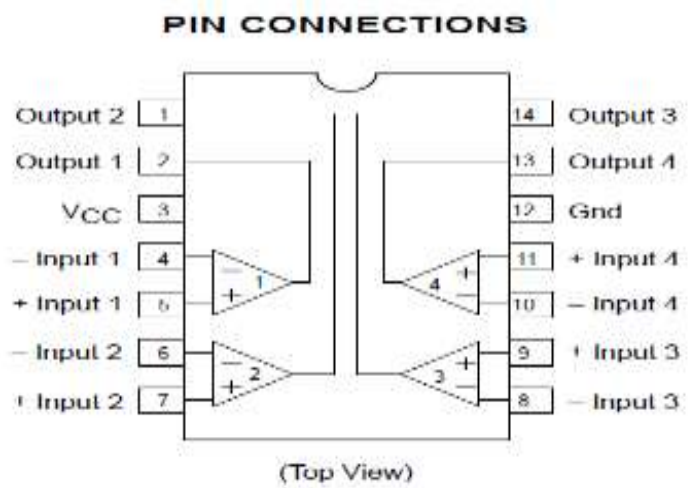

Figure 4. Connection diagram of the comparators LM339 
Control unit: As shown in Figures 5, 6 and 7, the control unit consists of the instruments that were used in the designed digital temperature of TAC1000HYC100, for temperature calibration and its wireless with USB sensor for reading the temperature within multimeter $\left(10 \mathrm{mv}=1^{\circ} \mathrm{C}\right)$, Figures 2, 3 and 4.

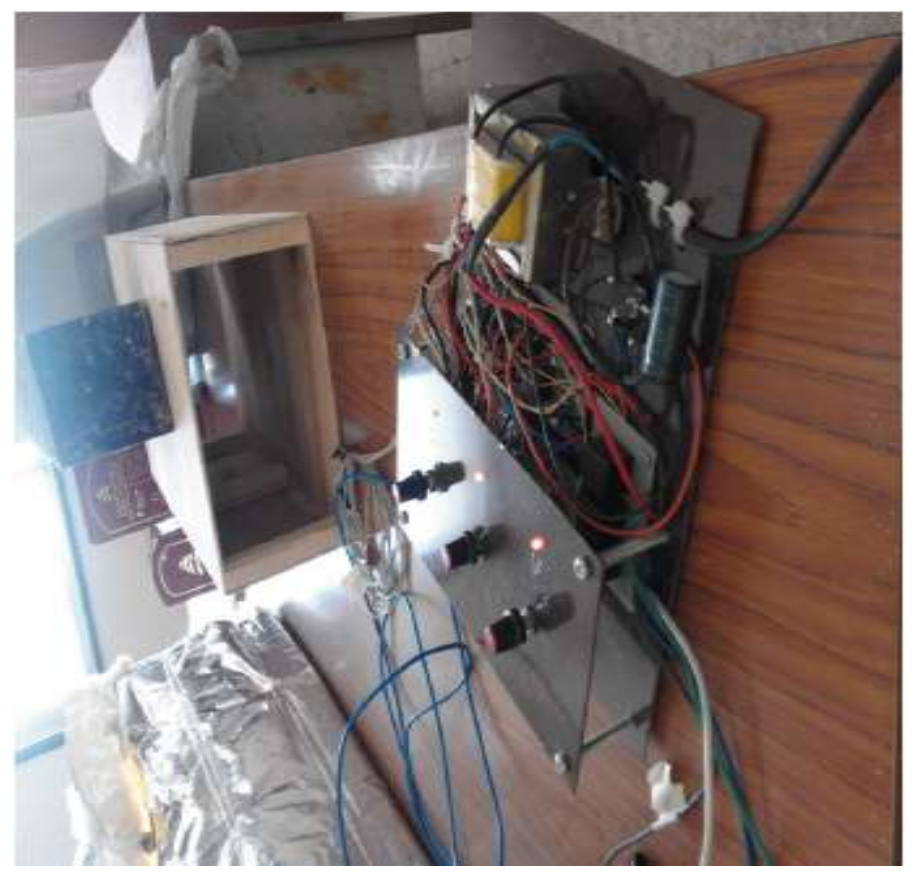

Figure 5. Photograph of temperature control panel unit

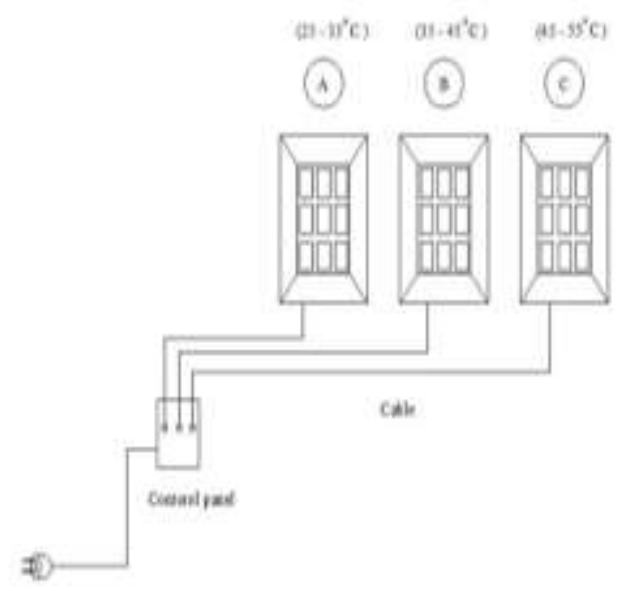

Figure 6. Schematic drawing of the temperature control unit 


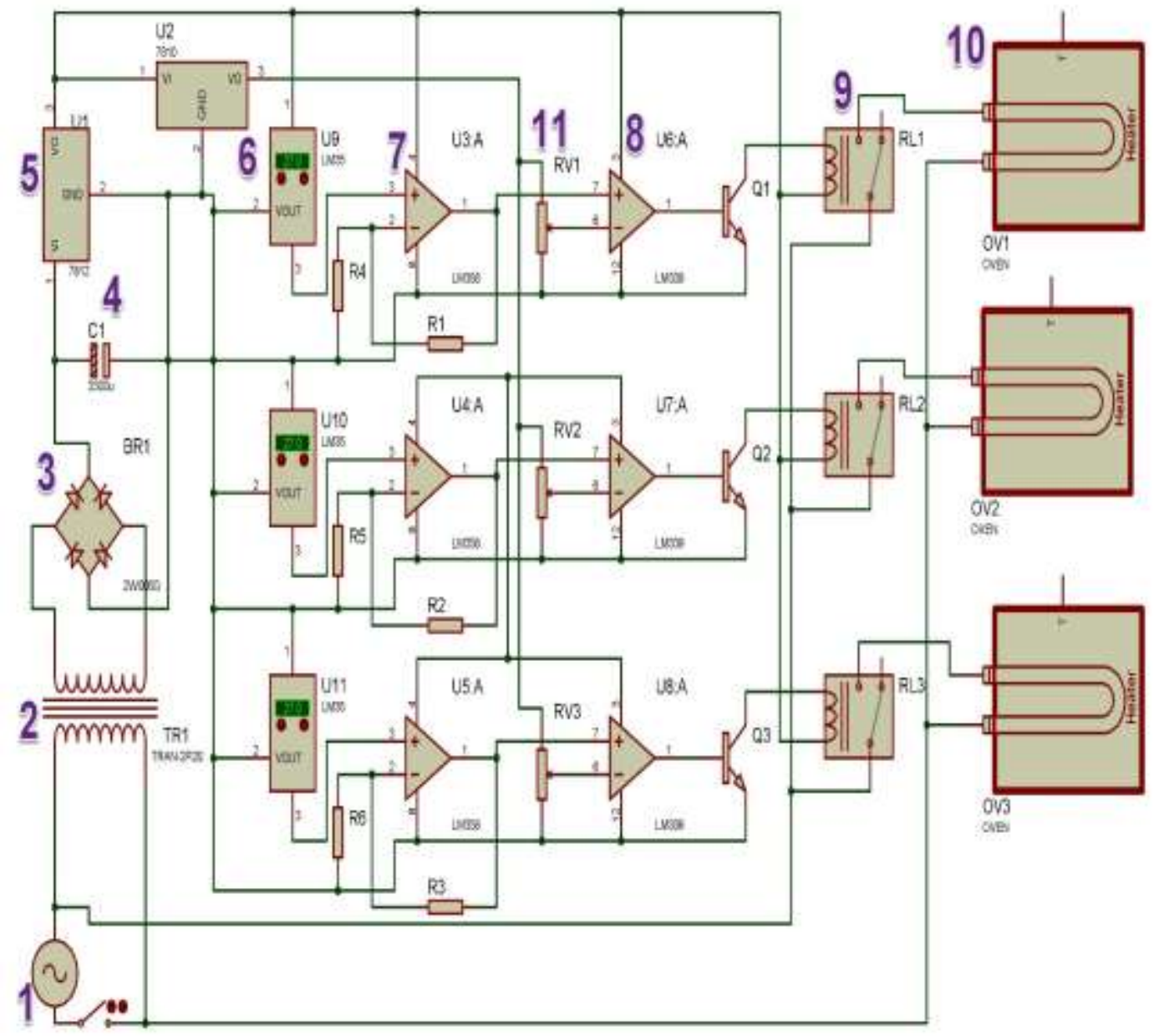

1 Electricity source 5 Voltage regulator

9 Relays $220 \mathrm{~V}$
2 Transformer
6 Temperature sensor 10 Heater 220/14V ofLM35
3 Bridge 4A
7 Operational amplifier of 11 Variable resistance (RV1- LM358 RV3)
4 Capacitors
8 Differential comparator 12 Resistor (R1-R6) of LM339

Figure 7. Schematic and engineering drawing of the control panel component (temperature control) 


\section{Measurements and Instrumentation}

\section{Determination of fish silage quality}

Silage extract was prepared by homogenizing 20g (wet material) from each variety and hybrid silage with $100 \mathrm{ml}$ distilled water in a blender for 10 minutes (Waldo and Schultz, 1956).

\section{Silage temperature during fermentation process}

For both the second and third experimental runs, every sample was used for measuring the fermentation temperature through the ensiling period, the interface analog digital converter model TU-1000 with measuring channels connected to thermocouples (type T).

\section{Silage moisture content}

Moisture was determined by placing an accurately weighed known of sample in a pre-weighted porcelain crucible in a hot air electric oven at $105^{\circ} \mathrm{C}$ for about 24 hours until constant weight was obtained.

\section{PH value}

$\mathrm{PH}$ value was directly measured using Orian 680 digital $\mathrm{pH}$ meter.

\section{Lactic acid}

Lactic acid was determined by titration with $0.1 \mathrm{~N}$ sodium hydroxide solution using $0.5 \mathrm{ml}$ of phenolphthalein indicator according to the method of Analytical Chemistry of Foods (1995).

\section{Total volatile fatty acids}

Total volatile fatty acids were determined according to the method of Wamer (1964).

\section{Determination of crude protein}

Nitrogen in the sample was estimated by following the micro kjeldhal method as outlined by Jackson (1973).

\section{Optical properties}

Fish silage optical properties was measured by a light source of laser lamb with light spectrum 630: 660nm (5mw) and digital lux meter device to measure the transmission light of silage samples with thickness of $1 \mathrm{~mm}$ position between two stripes of glass at thicknesses of 2,3 and $4 \mathrm{~cm}$.

\section{RESULTS AND DISCUSSION}

Effect of mixing ratio (Fish waste: Rice bran) on moisture content of silage process

Table 1 shows the relationship between the mixing ratio (fish waste: rice bran) and moisture content $\%$. With increasing fish waste at any mixed 
ratio increase moisture content, the optimal $\mathrm{PH}$ value for silage depends on its moisture content. The achieved mixing ratio of (fish waste: rice bran) was of (2.35:1) which gives moisture content of $62.3 \%$ wb was chosen according to (MAFR, 2006).

Table 1. Relationship between the mixing ratio (fish waste: rice bran) and moisture content, $\%$

\begin{tabular}{|l|l|}
\hline Mixing ratio ( fish waste : rice bran ) & MC , \%wb \\
\hline $1.5: 1$ & 52.2 \\
\hline $2.34: 1$ & 56.8 \\
\hline $3.35: 1$ & 62.3 \\
\hline $4: 1$ & 72.4 \\
\hline
\end{tabular}

\section{Effect of pressing pressure on silage $\mathrm{pH}$}

$\mathrm{pH}$ of all samples increased with time through the first days of fermentation then returned to its normal level at the end of ensiling period as shown Figure 9.

It is observed that at pressing pressure of $7.85 \mathrm{kPa}$. $\mathrm{pH}$ value was of 4.6 at the $5^{\text {th }}$ day and decreased even 3.35 at $30^{\text {th }}$ day while at pressing pressure of $12.75 \mathrm{kPa}, \mathrm{pH}$ value was of 4.55 at the $5^{\text {th }}$ day and decreased even 3.11 at $30^{\text {th }} \mathrm{day}$, at pressing pressure of $17.65 \mathrm{kPa}, \mathrm{pH}$ value was of 4.45 at the $5^{\text {th }}$ day and decreased even 3.11 at $25^{\text {th }}$ day and at pressing pressure of $22.56 \mathrm{kPa}, \mathrm{pH}$ value was of 4.2 at the $5^{\text {th }}$ day and decreased even 3.11 at $20^{\text {th }}$ day.

In general, the fermentation forces are controlled by formation of organic acids, mainly lactic acid by bacteria that grows in the presence of Limonstone. Sufficient lactic acids may form soluble sugar, which lower the $\mathrm{pH}$ of silage and restrict the activity of undesirable microorganisms. Nonliming microbial fermentation will continue until enough acid is produced to stop bacteria action. Moreover, it is a simple method to predict silage quality, but by itself it is unreliable because the optimal $\mathrm{pH}$ value for forage silage depends on the dry matter content. Generally, the prefer level of $\mathrm{pH}$ should be lower than 4.2 as mentioned by (Hossain, 2014).

In comparison of white and black coverage colors, the results illustrate that the black coverage color, formic acid addition 4\%, and pressing pressure of $22.56 \mathrm{kPa}$ were the optimal conditions for making silage. 


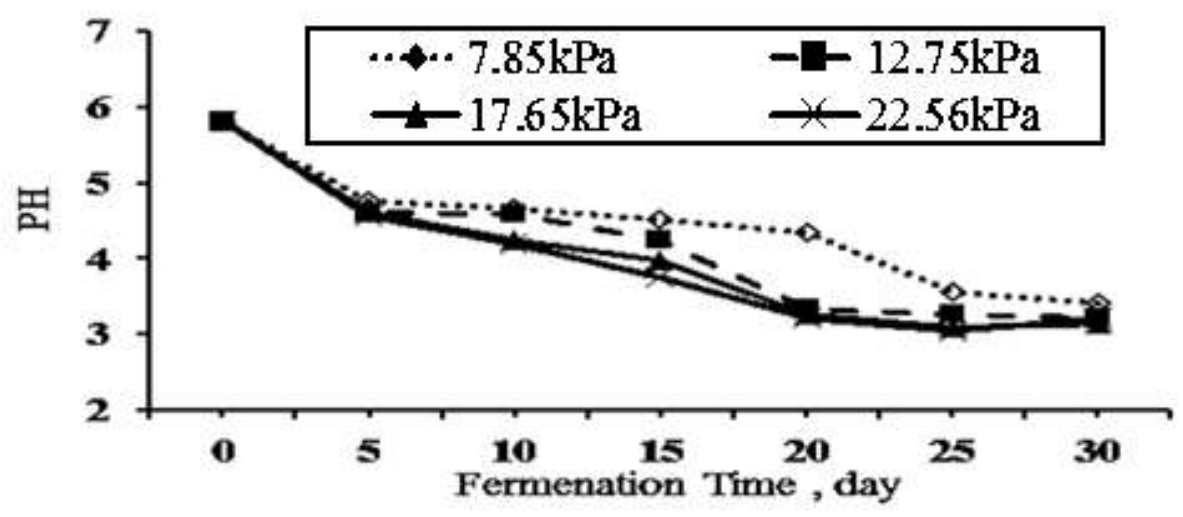

Figure 8. Silage $\mathrm{pH}$ behavior through the fermentation period at formic acid addition $4 \%$ and white coverage color

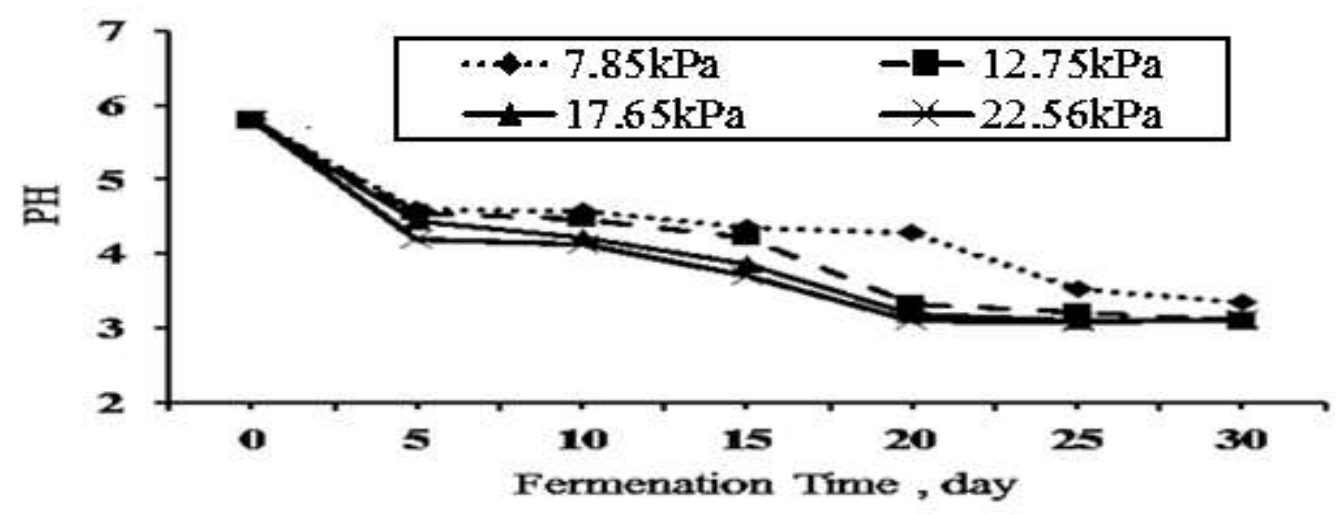

Figure 9. Silage $\mathrm{pH}$ behavior through the fermentation period at formic acid addition $4 \%$ and black coverage color

\section{Effect of coverage color addition on silage $\mathbf{p H}$}

As shown at Figure 10, black coverage color and formic acid addition 4\% decreasing $\mathrm{pH}$ value, because black coverage color helps on increasing the silage temperature and aerobic microorganism's losses minimum time and accelerates the fermentation. At formic acid addition 4\%, $\mathrm{PH}$ value was of 4.2 at black coverage color at $5^{\text {th }}$ day, 4.55 at white coverage color at $5^{\text {th }}$ day, 3.12 at black coverage color ( $30^{\text {th }}$ day), and 3.2 at white coverage color ( $30^{\text {th }}$ day). 


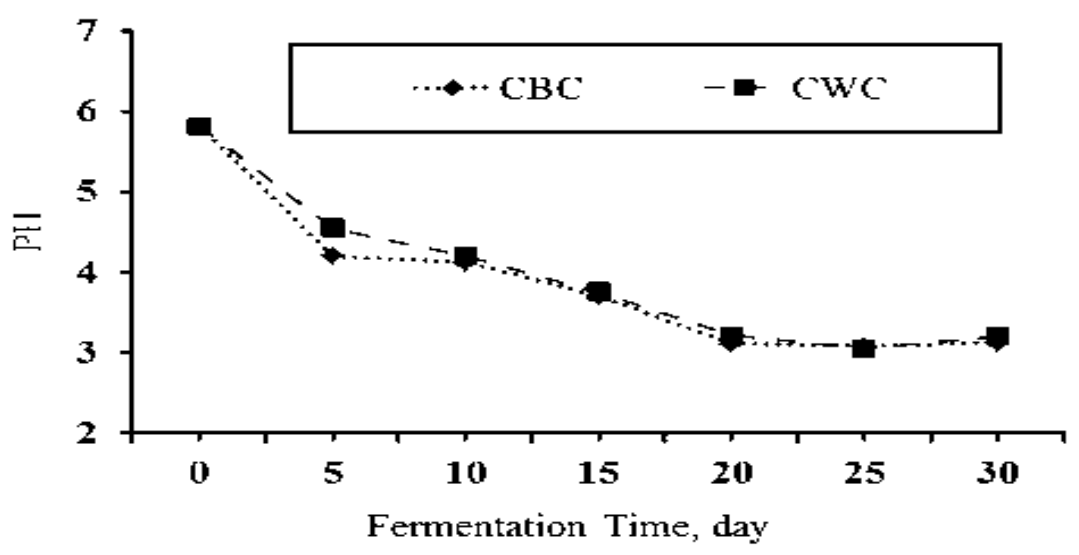

Figure 10. Silage $\mathrm{pH}$ behavior through the fermentation period under different coverage colors, white $\mathrm{CWC}$ and black $\mathrm{CBC}$, at pressing pressure of $22.56 \mathrm{kPa}$ and formic acid addition $4 \%$

\section{Effect of Formic acid addation percentage on silage $\mathbf{p H}$}

As shown in Figure 11, it was observed that high pessing pressure of $22.56 \mathrm{kPa}$ and formic acid addition $4 \%$, aerobic microorgansimes were killed because formic acid addition $4 \%$ helps on formation of LAB and decreases $\mathrm{pH}$ value. Silage $\mathrm{pH}$ was of 4.2 at $5^{\text {th }}$ day , 3.12 at $30^{\text {th }}$ day at black coverage color.

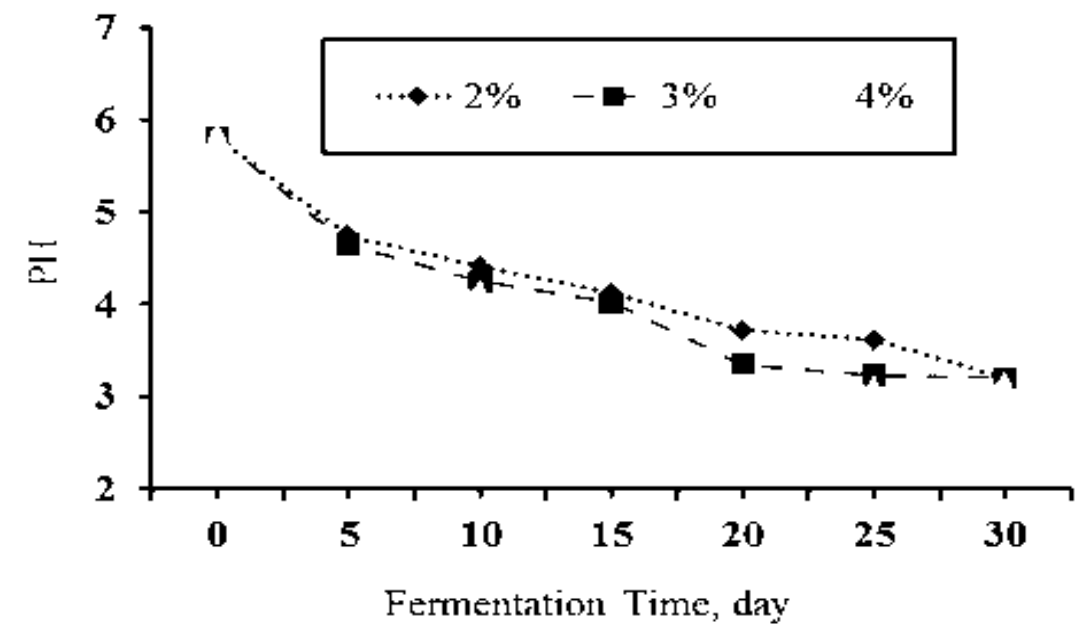

Figure 11. Effec Silage $\mathrm{pH}$ behavior through the fermentation period under different formic acid addition percentage at pressing pressure of $22.56 \mathrm{kPa}$ and black coverage color 


\section{Silage temperature}

Effect of the Engineering variables on physical and chemical characteristics of silage during ensiling process

The bulk temperature of all samples steadily increases with the fermentation time throughout the first days of fermentation process, until reaching its peak value, and then it was decreased to its normal level at the end of ensiling period as shown at Figure 12. Also, it was observed that as the pressing pressure increases at pressing pressure to be of $22.56 \mathrm{kPa}$ and formic acid addition increases up to $4 \%$, the $\mathrm{pH}$ of silage decreases and the temperature increases for its maximum level during fermentation time which helps to reduce fermentation period due to the extermration of aerobic microorganisms. As shown at Figure 13, formic acid addition 4\% and black coverage color, it was obseved that, at pressing pressure of $22.56 \mathrm{kPa}$, maximum silage temperature value was of $39.7^{\circ} \mathrm{C}$ at $10^{\text {th }}$ day, minimum silage temperature value was of $29.5^{\circ} \mathrm{C}$ at $5^{\text {th }}$ day.

In general, the silage temperature of all treatments not exceed $40^{\circ} \mathrm{C}$ which considered as excessive heating affecting the silage quality and lowers digestibility of all the produced silage. In the current study it is found that the optimal status was occurred pressing pressure of $22.56 \mathrm{kPa}$, formic acid addition $4 \%$ and black coverage color.

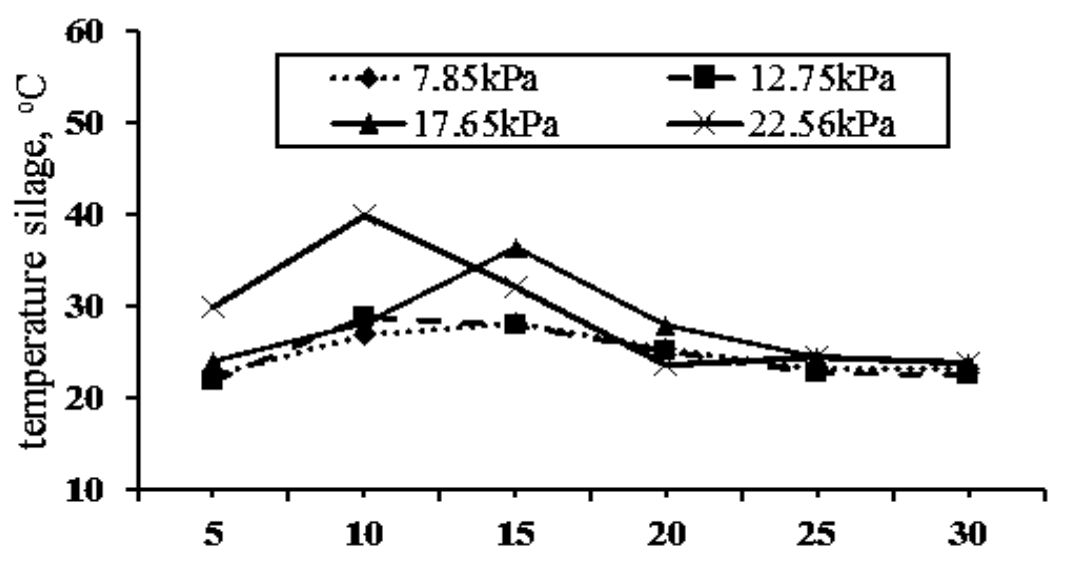

Fermentation time, day

Figure 12. Silage temperature behavior through the fermentation period at formic acid addition 4 and black coverage color 


\section{Silage Lactic Acid bacteria}

It's observed that as from Figure 13 the effect of different pressing pressures $(7.85,12.75,17.65$ and $22.56 \mathrm{kPa})$ on lactic acid bacteria value at different formic acid additions $4 \%$ and black coverage color. As pressing pressure increases from 7.85 to $22.56 \mathrm{kPa}$, lactic acid bacteria increase at all experimental treatments. It is observed that at pressing pressure of $7.85 \mathrm{kPa}$, lactic acid bacteria value was $4.31 \mathrm{~g} / \mathrm{kg}$ of dry matter at $9^{\text {th }}$ day and increases even 6.35 at $27^{\text {th }}$ day while at pressing pressure of $12.75 \mathrm{kPa}$, lactic acid bacteria value was of $4.58 \mathrm{~g} / \mathrm{kg}$ dry matter at $9^{\text {th }}$ day and increases even $6.35 \mathrm{~g} / \mathrm{kg}$ dry matter at $27^{\text {th }}$ day, at pressing pressure $17.65 \mathrm{kPa}$, lactic acid bacteria value was of $5.18 \mathrm{~g} / \mathrm{kg}$ dry matter at $9^{\text {th }}$ day and increases even $6.95 \mathrm{~g} / \mathrm{kg}$ dry matter at $27^{\text {th }}$ day and at pressing pressure $22.56 \mathrm{kPa}$, lactic acid bacteria value was $7.22 \mathrm{~g} / \mathrm{kg}$ dry matter at $9^{\text {th }}$ day and increases even $7.42 \mathrm{~g} / \mathrm{kg}$ dry matter at $27^{\text {th }}$ day. These results are within the values obtained by (Etman et al. 1994 and Gafar, 2001). So the optimal operating conditions were at pressing pressure of $22.56 \mathrm{kPa}$, formic acid addition $4 \%$ and black coverage color.

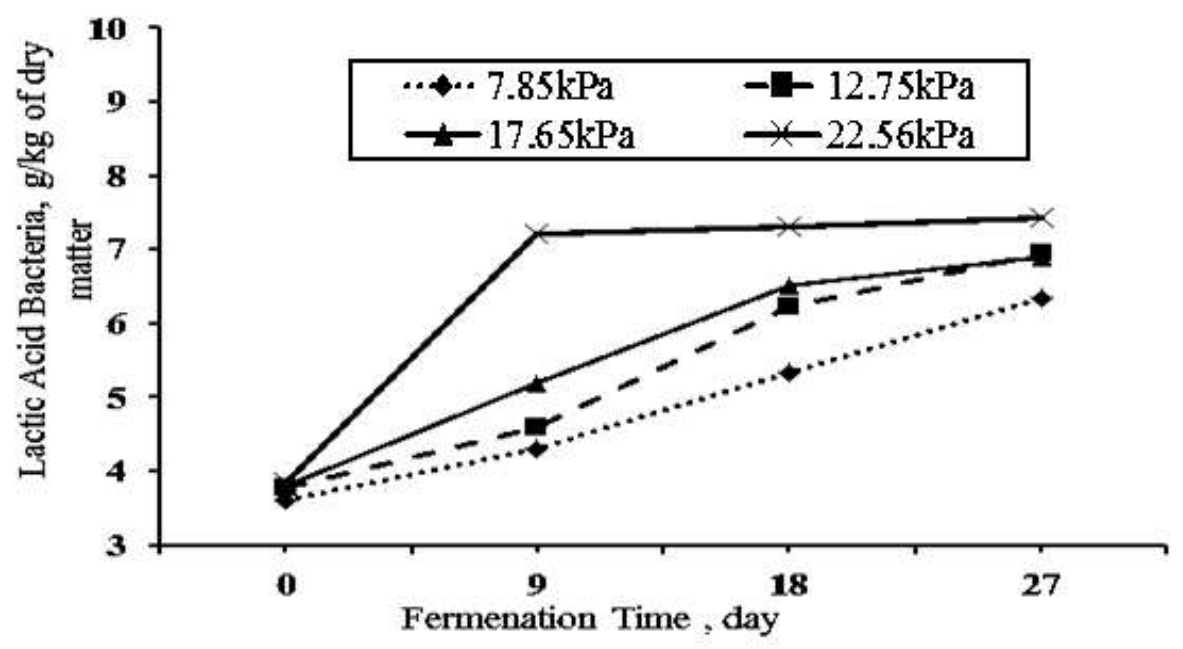

Figure 13. Effect of pressing pressure on silage lactic acid bacteria at formic acid addition $4 \%$ and black coverage color

\section{Silage Total volatile fatty acids (TVFA)}

The concentration of Total volatile fatty acids decreases as dry matter content. It was observed that from Figure 14 the effect of different 
pressing pressures $(7.85,12.75,17.65$ and $22.56 \mathrm{kPa})$ on Total volatile fatty acids value at formic acid addition $4 \%$ and black coverage color. Also, it was observed that increasing the pressing pressure from 7.85 to $22.56 \mathrm{kPa}$, total volatile fatty acids decreases for all experimental treatments. It is observed that at pressing pressure of $7.85 \mathrm{kPa}$, total volatile fatty acid's value was of $3.34 \mathrm{~g} / \mathrm{kg}$ at $9^{\text {th }}$ day and decreased even 1.83 at $27^{\text {th }}$ day. While at pressure of $12.75 \mathrm{kPa}$, total volatile fatty acid's value was of 3.38 at $9^{\text {th }}$ day and decreased even 1.63 at $27^{\text {th }}$ day. At pressing pressure $17.65 \mathrm{kPa}$, total volatile fatty acid's value was of 2.53 at $9^{\text {th }}$ day and decreased even 1.24 at $27^{\text {th }}$ day and at pressing pressure $22.56 \mathrm{kPa}$, total volatile fatty acid's value was of 1.78 at $9^{\text {th }}$ day and decreased even 1.23 at $27^{\text {th }}$ day. These results are within the values obtained by (Etman et al. 1994 and Gaafar, 2001).

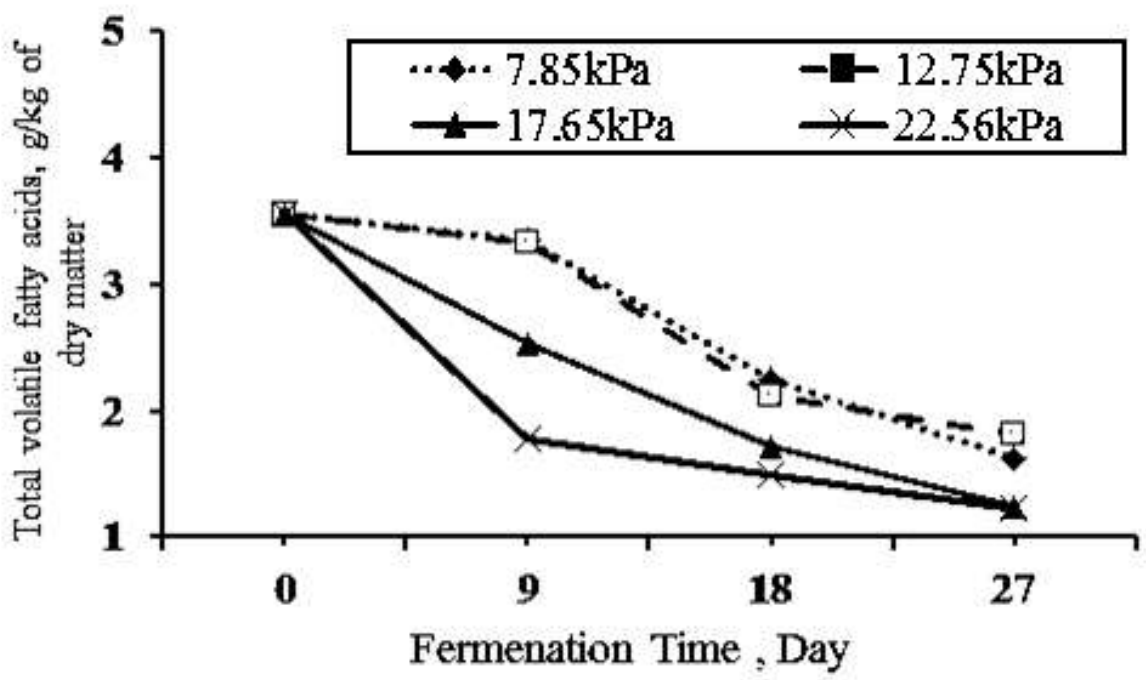

Figure 14. Silage Total volatile fatty acids at formic acid addition $4 \%$ and black coverage color under different pressing pressure

\section{The results of third expermental set up}

Effects of different ranges of temperature and different fermentation times on silage temperature at pressing pressure $22.56 \mathrm{~Pa}$, addition formic acid addition $4 \%$ and black coverage color. 
As shown in Table 2 , effect of different ranges of temperature and different fermentation times on silage temperature at pressing pressure $22.56 \mathrm{kPa}$, formic acid addition $4 \%$ and black coverage color. As shown in Figure 15, it is observed that at silage temperature of $(25-35)^{\circ} \mathrm{C}$, maximum silage temperature value was of $32^{\circ} \mathrm{C}$ at $6^{\text {th }}$ day, minimum silage temperature was of $23.5^{\circ} \mathrm{C}$ at $12^{\text {th }}$ day, at temperature $(35-45)^{\circ} \mathrm{C}$, maximum silage temperature value was of $34.3^{\circ} \mathrm{C}$ at $6^{\text {th }}$ day, minimum silage temperature was of $24.3^{\circ} \mathrm{C}$ at $12^{\text {th }}$ day, at temperature $(45-55)^{\circ} \mathrm{C}$, maximum silage temperature value was of $36.1^{\circ} \mathrm{C}$ at $6^{\text {th }}$ day, minimum silage temperature was of $23.4^{\circ} \mathrm{C}$ at $12^{\text {th }}$ day. So the best range temperature was of $(45-55)^{\circ} \mathrm{C}$ because of the high range of temperature accelerates the harvesting silage and decreases the harvest time.

Table 2. Effect of different ranges of temperature and different fermentation times on silage temperature at pressing pressure $22.56 \mathrm{~Pa}$, formic acid addition $4 \%$ and black coverage color.

\begin{tabular}{|c|c|c|c|c|c|c|c|c|}
\hline \multirow{2}{*}{$\begin{array}{l}\text { The ranges } \\
\text { of } \\
\text { temperature }\end{array}$} & \multicolumn{2}{|c|}{$3^{\text {rd }}$ day } & \multicolumn{2}{|c|}{$6^{\text {th }}$ day } & \multicolumn{2}{|c|}{$9^{\text {th }}$ day } & \multicolumn{2}{|c|}{$12^{\text {th }}$ day } \\
\hline & $\begin{array}{c}\text { Ambient } \\
\text { Temperature }\end{array}$ & $\begin{array}{c}\text { Silage } \\
\text { Temperature }\end{array}$ & $\begin{array}{c}\text { Ambient } \\
\text { Temperature }\end{array}$ & $\begin{array}{c}\text { Silage } \\
\text { Temperature }\end{array}$ & $\begin{array}{c}\text { Ambient } \\
\text { Temperature }\end{array}$ & $\begin{array}{c}\text { Silage } \\
\text { Temperature }\end{array}$ & $\begin{array}{l}\text { Ambient } \\
\text { Temperature }\end{array}$ & $\begin{array}{c}\text { Silage } \\
\text { Temperature }\end{array}$ \\
\hline$(25-35)^{\circ} \mathrm{C}$ & 19.5 & 26 & 20 & 32 & 20.5 & 28 & 20 & 23.5 \\
\hline$(35-45)^{\circ} \mathrm{C}$ & 19.5 & 28.2 & 20 & 34.3 & 20.5 & 27.1 & 20 & 24.1 \\
\hline$(45-55)^{\circ} \mathrm{C}$ & 19.5 & 31.2 & 20 & 36.1 & 20.5 & 25.3 & 20 & 23.4 \\
\hline
\end{tabular}

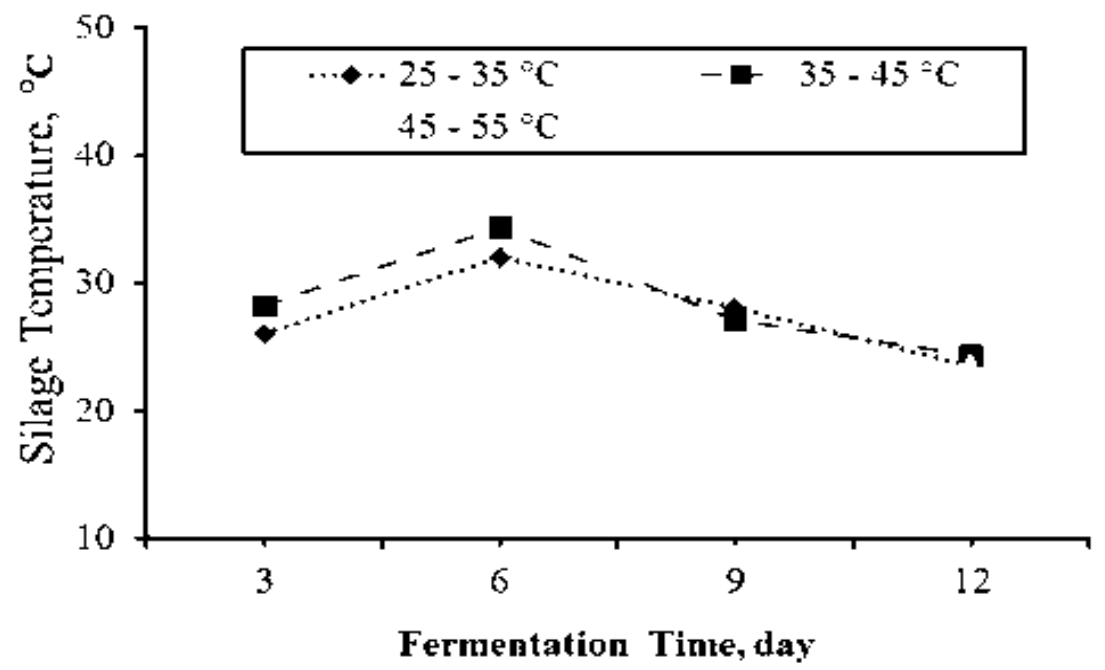

Figure 15. Silage temperature through the fermentation time under 
different temperature control rages at pressing pressure of $22.56 \mathrm{kPa}$, formic acid addition $4 \%$ and black coverage color

\section{Optical properties of silage quality}

The effect of three different ranges of temperature $(45-55)^{\circ} \mathrm{C},(35-$ $45)^{\circ} \mathrm{C}$ and $(45-55)^{\circ} \mathrm{C}$, lactic acid bacteria value, $\mathrm{pH}$ value, crude protein, Total volatile fatty acids on the intensity of illumination at three thicknesses (2, 3 and $4 \mathrm{~cm})$ were studied.

Table 3 shows that the effect of different fermentation times, different $\mathrm{pH}$ values, different thicknesses of silage samples and different silage temperatures on the intensity of illumination. It noticed that decreasing $\mathrm{PH}$ value caused increasing in the intensity of illumination at all the investigated variables. The best state was at temperature range of (45$55)^{\circ} \mathrm{C}$ and thickness of $4 \mathrm{~cm}$ at any fermentation time. The intensity of illumination value was of $44.5,47.3,53.3$ and 58.3 at thickness $4 \mathrm{~cm}$ at fermentation time at $3^{\text {rd }}, 6^{\text {th }}, 9^{\text {th }}$ and $12^{\text {th }}$ day respectively.

Table 3. Illumination intensity of fish silage under different production conditions

\begin{tabular}{|c|c|c|c|c|c|c|c|c|c|c|c|c|c|c|c|c|}
\hline \multirow{5}{*}{$\begin{array}{l}\text { Differe } \\
\text { nt } \\
\text { ranges } \\
\text { of } \\
\text { tempera } \\
\text { ture }\end{array}$} & \multicolumn{16}{|c|}{ Fermentation time } \\
\hline & \multicolumn{4}{|c|}{$3^{\text {rd }}$ day } & \multicolumn{4}{|c|}{$6^{\text {th }}$ day } & \multicolumn{4}{|c|}{$9^{\text {th }}$ day } & \multicolumn{4}{|c|}{$12^{\text {th }}$ day } \\
\hline & \multirow[t]{3}{*}{$\mathrm{pH}$} & \multicolumn{3}{|c|}{$\begin{array}{l}\text { Intensity of } \\
\text { illumination, } \\
\text { lumen } / \mathrm{m}^{2}\end{array}$} & \multirow[t]{3}{*}{$\mathrm{pH}$} & \multirow{2}{*}{\multicolumn{3}{|c|}{$\begin{array}{l}\text { Intensity of } \\
\text { illumination, } \\
\text { lumen } / \mathrm{m}^{2} \\
\text { Thickness, cm }\end{array}$}} & \multirow[t]{3}{*}{$\mathrm{pH}$} & \multirow{2}{*}{\multicolumn{3}{|c|}{$\begin{array}{l}\text { Intensity of } \\
\text { illumination, } \\
\text { lumen } / \mathrm{m}^{2}\end{array}$}} & \multirow[t]{3}{*}{$\mathrm{pH}$} & \multicolumn{3}{|c|}{$\begin{array}{l}\text { Intensity of } \\
\text { illumination, } \\
\text { lumen } / \mathrm{m}^{2}\end{array}$} \\
\hline & & \multicolumn{3}{|c|}{ Thickness, cm } & & & & & & & & & & \multicolumn{3}{|c|}{ Thickness, $\mathrm{cm}$} \\
\hline & & 2 & 3 & 4 & & 2 & 3 & 4 & & 2 & 3 & 4 & & 2 & 3 & 4 \\
\hline$(25-35)^{\circ} \mathrm{C}$ & 4.95 & 39 & 41 & 42.1 & 4.6 & 43 & 47 & 47.9 & 3.95 & 49 & 51.8 & 52.85 & 3.28 & 51 & 69 & 70.3 \\
\hline$(35-45)^{\circ} \mathrm{C}$ & 4.71 & 40.2 & 42.2 & 43.5 & 4.1 & 44.5 & 45.7 & 46.42 & 3.52 & 50.13 & 52.1 & 54.1 & 3.31 & 53.2 & 54.91 & 55.9 \\
\hline$(45-55)^{\circ} \mathrm{C}$ & 4.45 & 41 & 43.2 & 44.5 & 3.85 & 45.1 & 46.2 & 47.3 & 3.32 & 50.3 & 53.2 & 55.3 & 3.25 & 53.2 & 55.1 & 58.3 \\
\hline
\end{tabular}

\section{CONCLUSIONS}

The obtained results can be summarized as follows:

1. The best mixed ratio was 3.35: 1 and gives moisture content $62.3 \%$ wb.

2. At pressing pressure of $7.85 \mathrm{kPa}$, formic acid addition percentage 4 $\%$ and coverage with the black color, the $\mathrm{PH}$ value was of 3.35 , total volatile fatty acids value was of $1.83 \mathrm{~g} / \mathrm{kg}$ dry matter, lactic acid bacteria value was of $6.35 \mathrm{~g} / \mathrm{kg}$ dry matter, silage maximum temperature was $28.2^{\circ} \mathrm{C}$, harvest time at $30^{\text {th }}$ day. 
3. At pressing pressure of $12.75 \mathrm{kPa}$, formic acid addition $4 \%$ and coverage with the black color, the $\mathrm{pH}$ value was 3.11 , total volatile fatty acids value was of $1.36 \mathrm{~g} / \mathrm{kg}$ dry matter, lactic acid bacteria value was $6.91 \mathrm{~g} / \mathrm{kg}$ dry matter, silage maximum temperature was $28.7^{\circ} \mathrm{C}$, harvest time at $30^{\text {th }}$ day.

4. At pressing pressure of $17.65 \mathrm{kPa}$, formic acid addition $4 \%$ and coverage with the black color, the $\mathrm{pH}$ value was of 3.1, total volatile fatty acids value was of $1.31 \mathrm{~g} / \mathrm{kg}$ dry matter, lactic acid bacteria value was $6.95 \mathrm{~g} / \mathrm{kg}$ dry matter, silage maximum temperature was $38.03^{\circ} \mathrm{C}$, harvest time at $25^{\text {th }}$ day.

5. At pressing pressure of $22.56 \mathrm{kPa}$, formic acid addition $4 \%$ and coverage with the black color, the PH value was of 3.12, total volatile fatty acids value was of $1.32 \mathrm{~g} / \mathrm{kg}$ dry matter, lactic acid bacteria value was $7.42 \mathrm{~g} / \mathrm{kg}$ dry matter, silage maximum temperature was $39.75^{\circ} \mathrm{C}$, harvest time at $20^{\text {th }}$ day.

The best experimental treatment was at pressing pressure of $22.56 \mathrm{kPa}$, formic acid addition $4 \%$ and black coverage color.

6. At range of control in temperature $(45-55)^{\circ} \mathrm{C}$, the results $\mathrm{pH}$ value was of 3.25 , total volatile fatty acids was $1.95 \mathrm{~g} / \mathrm{kg}$ dry matter, lactic acid bacteria value was of $6.2 \mathrm{~g} / \mathrm{kg}$, curde protein was $36.12 \mathrm{~g} / \mathrm{kg}$ dry matter, temperature in the end of fermentation period maximum was $36.1^{\circ} \mathrm{C}$, at $6^{\text {th }}$ day, minimum was $23.4^{\circ} \mathrm{C}$ at $9^{\text {th }}$ day, harvesting time at $9^{\text {th }}$ day.

7. The intensity of illumination value was $44.5,47.3,53.3$ and 58.3 lumen $/ \mathrm{m}^{2}$ at thickness $4 \mathrm{~cm}$ at fermentation time $3^{\text {rd }}, 6^{\text {th }}, 9^{\text {th }}$ and $12^{\text {th }}$ day respectively.

The biological value of fish silage and fish silage were found to be very high, since all essential nutrients were present in fairly appropriate concentration. So, it is possible to use the powder fish silage and fish silage in fish feed cost and enhanced aquaculture production.

\section{REFERENCES}

Abdallah, S. E.; W. M. Elmessery; A. A. Elkeway and M. M. Abdelaal. 2017. Utilization of Heat Exchangers in Drying of Fish Farm Wastes for the Production of Feed Concentrates. Misr Journal of Agricultural Engineering, 34(1): 487 - 524. 
Abowei, J. F. N and C. C. Tawari. 2011. Some basic principles of fish processing in Nigeria. Asian Journal of Agricultural Sciences, 3(6):437-452.

AMedrzyck, K and R. T. Wandzei. 2013. Preparation, Composition and proportion of fish silage produced with post- coagulation sludge. Environment Protection Engineering, 39(3): 39-49.

Analytical Chemistry of foods. 1995. Published by Blockier academic and professional, an imprint of chapman \& Hall, western cleddens Road, Bishop Briggs, Glasgow G64 2NZ, UK.

Archer, M. R.; R. Watson and J. W. Denton. 2001. Fish waste production in the United Kingdom-The quantities produced and opportunities for better utilization. Sea fish Technology, 537: 4-5.

Arruda, L. F. D; R. Borghesi and M. Oetterer .2007: Use of fish waste as silage- a review. Brazilian Archives of Biology and Technology, 50(5): 879-886.

ASAE. 1998. Moisture relationships of plan- based agricultural products. ASAE standard D245.5, AM. Soc. Agriculture. Engineering. St. Joseph. MI.

Chen, Q. 2009. Corn Stover with enzymes as feedstock preservation methods for bioconversion. Unpublished thesis, Ph. D. United States of America.

Cicero, A and G. Derosa. 2005. Rice bran and its main components: potential role in the management of coronary risk factors. Current Topics in Nutraceutical Research, 3(1): 29-46.

DOF. 2013. National Fish Week 2013 Compendium (in Bengali). Department of Fisheries, Ministry of Fisheries and Livestock, Dhaka, Bangladesh, pp.144.

El kholy, M. M; A. M. Matouk; A. Esadany and Y. Hendawy. 2009. Factors affecting on rice brain oil extraction using hydraulic press unit. Misr Journal of Agricultural Engineering, 26(1): 306 - 323.

Etman, K.I.; E.A. Khafagi; W.H. Abd El-Malik; M.K. Hathut and M.F. El-Sayes. 1994. Conservation of green summer forages as silage 
and its utilization in feeding growing lambs. Egyptian Journal Animal of Production, 131:175.

Gaafar, H. M. 2001. Performance of growing calves fed rations contain corn silage. Unpublished thesis Ph.D., Faculty of Agriculture, Kafr Elsheikh, Tanta university.

Goddard, J. S and J. S. M. Perret . 2005. Co-drying fish silage for use in aqua feeds. Animal Feed Science and Technology, 118: 337-342.

Hancock, D. W and M. Collins. 2006. Forage preservation method influences alfalfa nutritive value and feeding characteristics. Crop Science, 46: 688-694.

Hanafy, M. A and S. M. Ibrahim. 2004. Storage stability of yogurt fermented fish silage. Journal of Egyptian Academic Social and Environmental Development, 5: 23-41.

Hossain, U. 2014. Production of powder fish silage from fish market wastes. Unpublished. M.Sc. Thesis, Department of Fisheries Technology, Bangladesh Agricultural University, Mymensingh.

Jackson, M. L. 1973. Soil Chemical Analysis, Oxford and IBH Publishers, Bombay.

Karim, N. U; M. F. Mohd and A. M. Arshod. 2015. The effectiveness of fish silage as organic fertilizer on postharvest quality of pack choy, malaysis. European International Journal of Science and Technology, 4(5): $164-176$.

MAFRI. 2006. An introduction to silage. Manitoba Agriculture, Food and Rural Initiatives. www. gov.mb.ca/agriculture/crops/forages/bjboos16.html. Accessed on 20 December 2016.

Oetterer, M. 2002. Industrializacao do pescado cultivado Livraria e Editora Agropecuária, Guaiba, RS-Brasil, pp. 200.

Rose, M. V; M. M. Elisabete and J. C. Dalton. 2003. Amino acid composition of processed fish silage using different raw materials. Animal Feed Science and Technology, 105: 199-204.

Waldo, D. R. and L. H. Schultz. 1956. Lactic acid production in the rumen. Dairy Science, 39: 1455. 


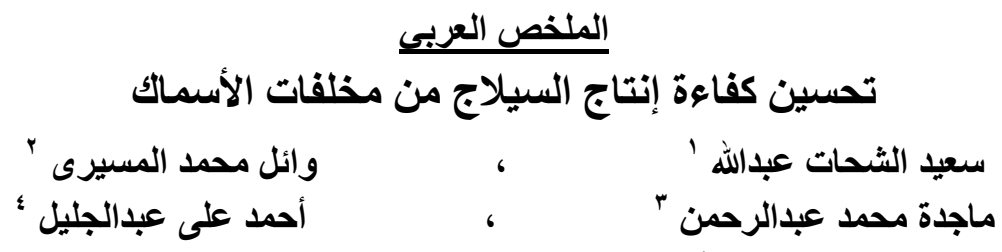

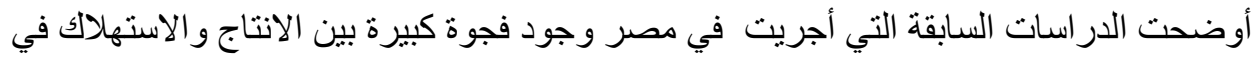

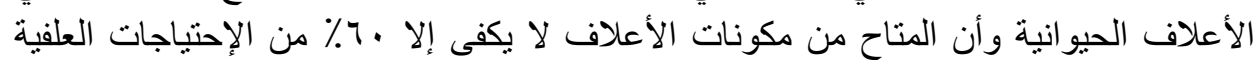

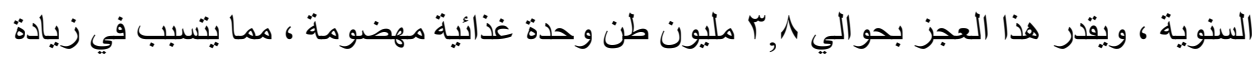

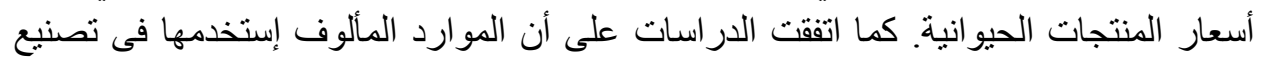

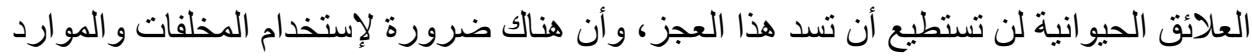

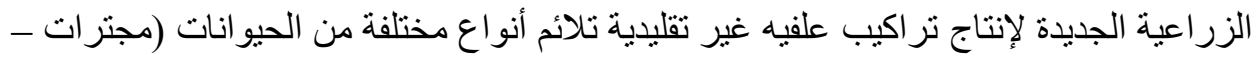

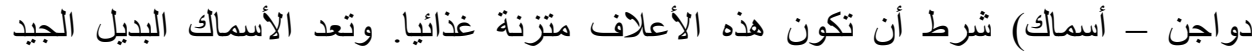
و المناسب في الجودة والسعر لسد الفجوة الغذائية في البرونين الحيواني خاصة مع الإرتفاع الكبير في أسعار اللحوم الحمر اءو الدودة واجن. ولما كانت عمية السيلجة هي المعاملة المثلى للتخلص من مخلفات الاسماك بطريقة صحية وأمنه المنه

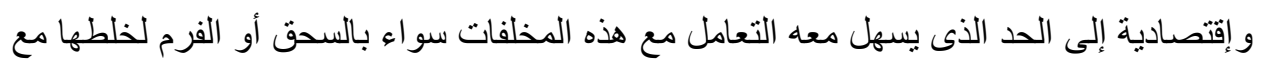

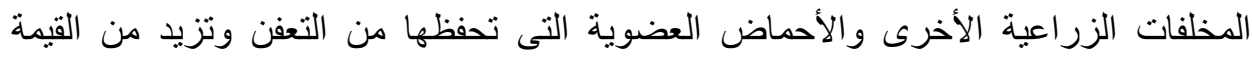

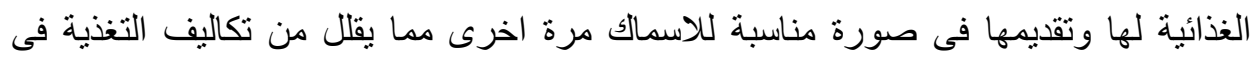

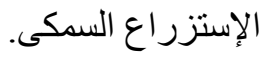

وكان الهدف العام من الدراسة هو تقليل فترة حصـاد السيلاج السمكي وإيجاد أعلاف بديلة تقليدية من مخلفات الإنتاج الزرام اعي و السمكي. بينما الأهداف الفرعية هى على النحو التالى :

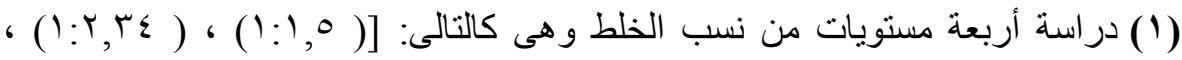

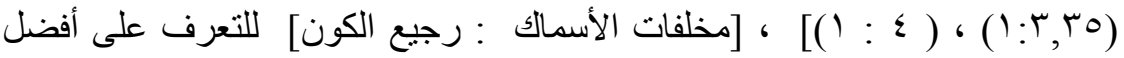
نسبة خلط لعمل السيلاج. (Y) تأثثر ثثلاث إضافات مختلفة من الفورمك أسبد ( r ، r ، ع) ) ، على وقت حصاد السيلاج.

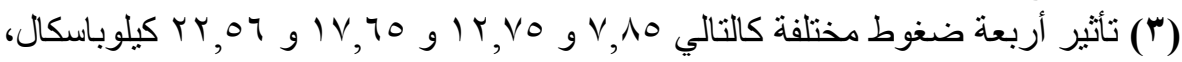
على وقت حصاد السيلاج السمكى.

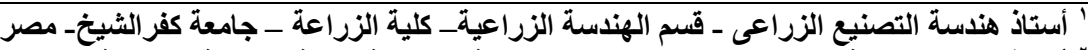

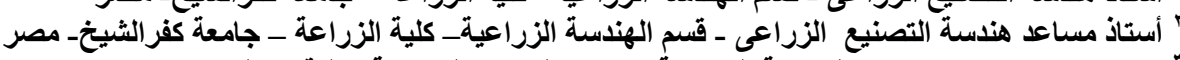

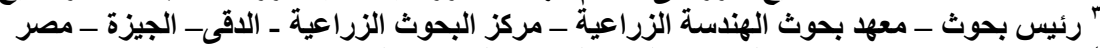

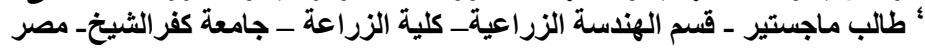




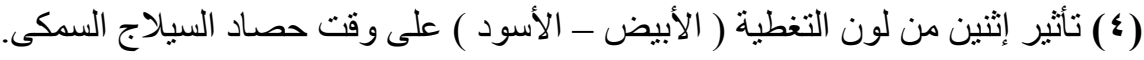

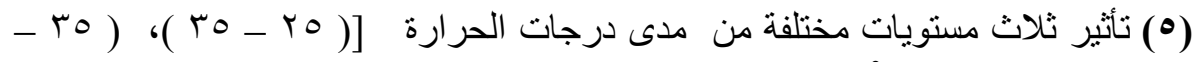

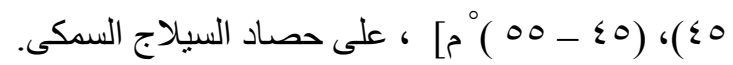
و خلصت الاراسة إلى النتائج التالية:

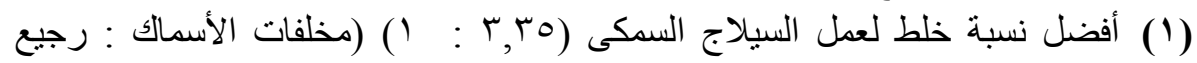

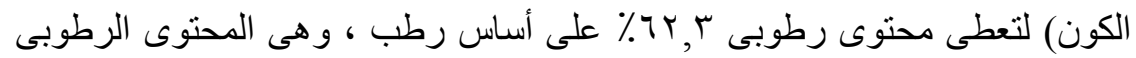
الآمن لعمل السيلاج.

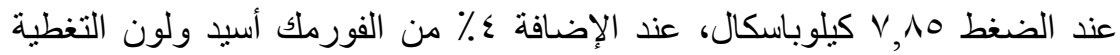

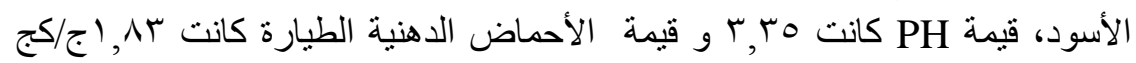

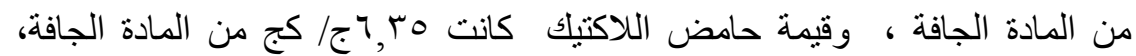

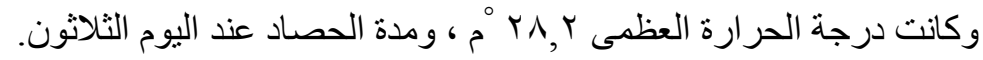

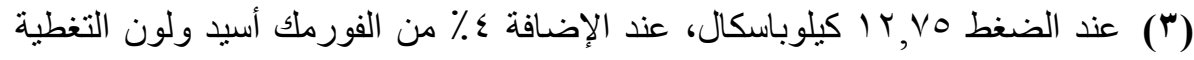

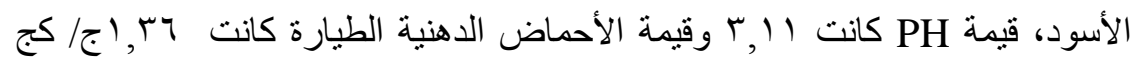

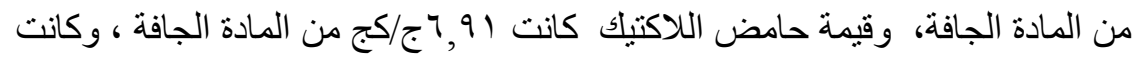

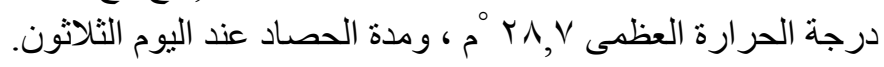

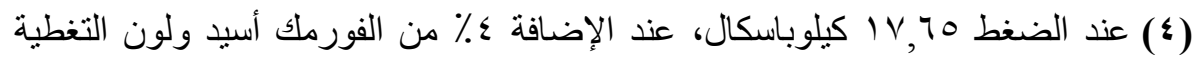

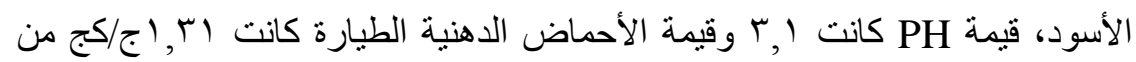

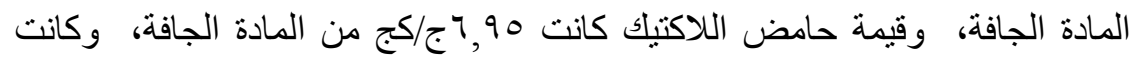

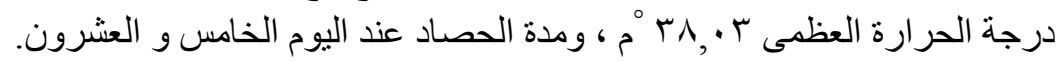

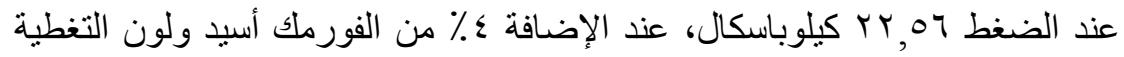

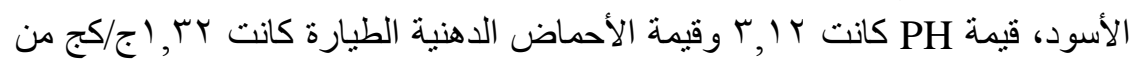
$\left({ }^{\circ}\right)$

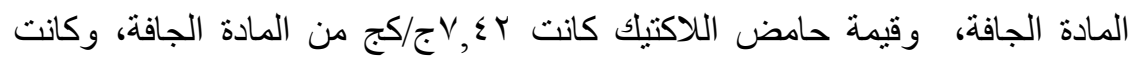

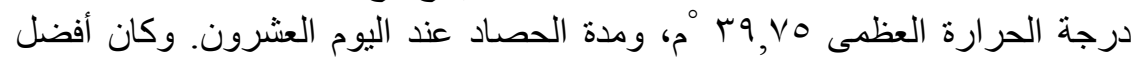

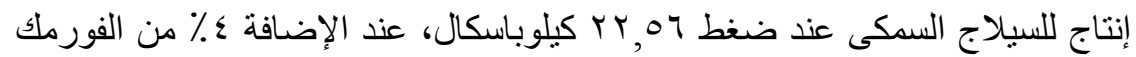

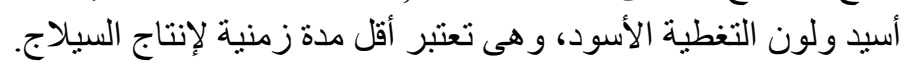

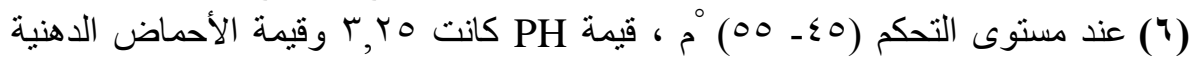

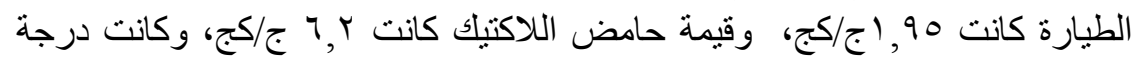

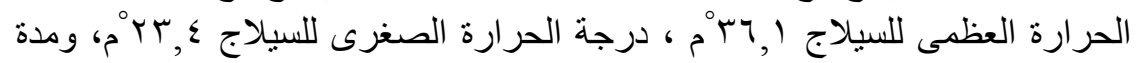

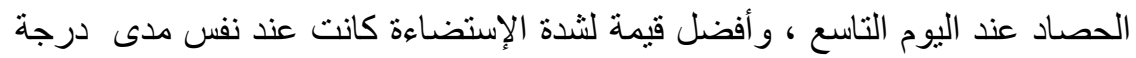

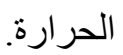

\section{التوصيات العملية المستقبلية}

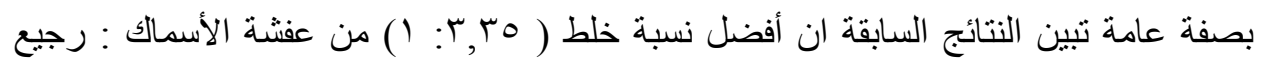

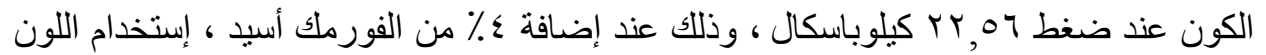

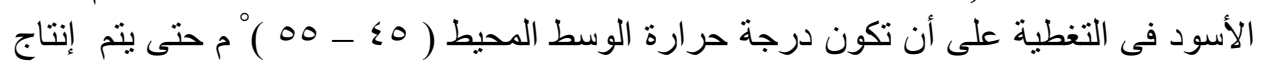
سيلاج سمكى عالى القيمة الغذائية. 